\title{
ЕКСПЕРИМЕНТАЛЬНІ АОСЛІАЖЕННЯ
}

\section{ЗМІНИ РЕДОКС-СТАНУ РЕГЕНЕРУЮЧОЇ ПЕЧІНКИ ПІД ВПЛИВОМ ЕЛЕКТРОМАГНІТНОГО ОПРОМІНЕННЯ}

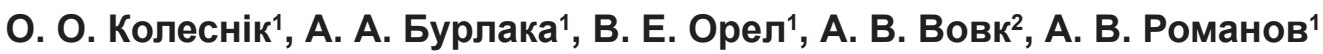 \\ ${ }^{1}$ Національний інститут раку, м. Київ,
}

${ }^{2}$ Інститут експериментальної патології, онкології і радіобіології імені Р. Є. Кавецького НАН України, м. Київ

\section{THE CHANGES OF REDOX STATE IN REGENERATING LIVER UNDER THE INFLUENCE OF ELECTRIC-MAGNET IRRADIATION}

\author{
O. O. Kolesnik ${ }^{1}$, A. A. Burlaka1, V. E. Orel' ${ }^{1}$, A. V. Vovk², A. V. Romanov ${ }^{1}$ \\ ${ }^{1}$ National Institute of Cancer, Kyiv, \\ ${ }^{2}$ Kavetskyi Institute of Experimental Pathology, Oncology and Radiobiology, Kyiv
}

\begin{abstract}
Реферат
В експерименті після часткової резекції печінки проводили 5 сеансів ії локального неоднорідного електромагнітного опромінення (EMO) з частотою 42 МГц та вихідною потужністю 75 Вт. Температура всередині печінки не перевищувала $38^{\circ} \mathrm{C}$. Для дослідження редокс-стану вивчали спектри електронного парамагнітного резонансу (ЕПМР) після повної гепатектомії на 7-му добу після часткової резекції печінки на основі аналізу спектру ЕПМР. Маса печінки після ії часткової резекції на 7-му добу та курсу ЕМО була на 19,5\% більша, ніж у неопромінених тварин. Рівень убісеміхінону в електронотранспортному ланцюзі (ЕТЛ) мітохондрій в регенеруючій печінці тварин після ЕМО був на $45 \%$ меншим $(p<0,05)$ порівняно з таким у лише оперованих тварин. Зміни редокс-стану регенеруючої печінки підтверджені також зменшенням рівня білка церулоплазміну в 2,2 разу у крові тварин після резекції та ЕМО порівняно з таким в оперованих тварин. Це свідчить про взаємозв'язок змін редокс-стану регенеруючої печінки під впливом EMO з метаболічними процесами в усьому організмі. Отримані результати свідчать про перспективи використання синергетичного впливу ЕМО та наномагнітних структур для дистанційного керування редокс-станом і кінетикою проліферації клітин при регенерації печінки після ії резекції у пацієнтів при онкологічних захворюваннях.

Ключові слова: печінка; регенерація; електромагнітне поле; редокс-стан; електронний парамагнітний резонанс; експеримент.

Abstract

In experiment after partial hepatic resection 5 séances of its local impure electromagnet irradiation (EMI) with frequency $42 \mathrm{MHz}$ and output potency $75 \mathrm{~W}$ were conducted. Hepatic temperature inside the organ did not exceed $38^{\circ} \mathrm{C}$. For investigation of redox state the spectrums of electronic paramagnetic resonance (EPMR) were studied after total hepatectomy on the 7th day after partial hepatic resection, basing on analysis of the EPMR spectrum. Hepatic mass after its partial resection on the 7th day and the EMI course were by $19.5 \%$ points more, than in nonirradiated laboratory animals. Level of ubisemichinone in the electron-transporting chain of mitochondria in regenerating liver of laboratory animals after EMI was by $45 \%$ less $(p<0.05)$, comparing with such in the operated only laboratory animals. The redox state changes in regenerating liver were confirmed by reduction of the protein cerulloplasmine level in 2.2 times in the blood of laboratory animals after resection and EMI, comparing with such in nonoperated laboratory animals. This witness the interrelationship of the redox state changes in regenerating liver under the influence of EMI with metabolic processes in organism as a whole. The results obtained witness the perspectives for application of synergetic impact of EMI and nano-magnet structures for distant governing of redox state and kinetics of cellular proliferation while process of hepatic regeneration occur after its resection in patients, suffering oncological diseases.

Keywords: liver; regeneration; electro-magnet field; redox state; electronic paramagnetic resonance; experiment.
\end{abstract}

Показники п'ятирічного виживання хворих після резекції метастазів колоректального раку в печінці близькі до 25\%. Рецидиви під час регенерації печінки виникають у 66\% пацієнтів після операції. Підбір пацієнтів, які мають позитивні перспективи від операції, є спірним і суб'єктивним. Негативна побічна реакція хірургічного втручання - ішеміяреперфузія - спричиняє ушкодження печінки, формування гострої пе- чінкової недостатності після резекціï, а також трансплантації печінки $[1,2]$.

Процес регенерації печінки ініціюють специфічні зовнішні стимули за участю послідовних змін експресії генів, факторів росту, морфологічної структури. У виникненні реперфузійного пошкодження важливу роль відіграє редокс-стан регенеруючої печінки. Редокс-залежні сигнальні молекули можуть функ- ціонувати як регуляторні сигнали в основних клітинних процесах, у тому числі при регенерації печінки, та контролювати клітинний цикл за участю фактору транскрипції Nrf2 [3-5].

Одним з чинників, що використовують для впливу на редокс-реакції для стимуляції регенерації тканин, $є$ ЕМО. Вплив електромагнітного поля посилює процес регенерації печінки, він завершується більш швид- 

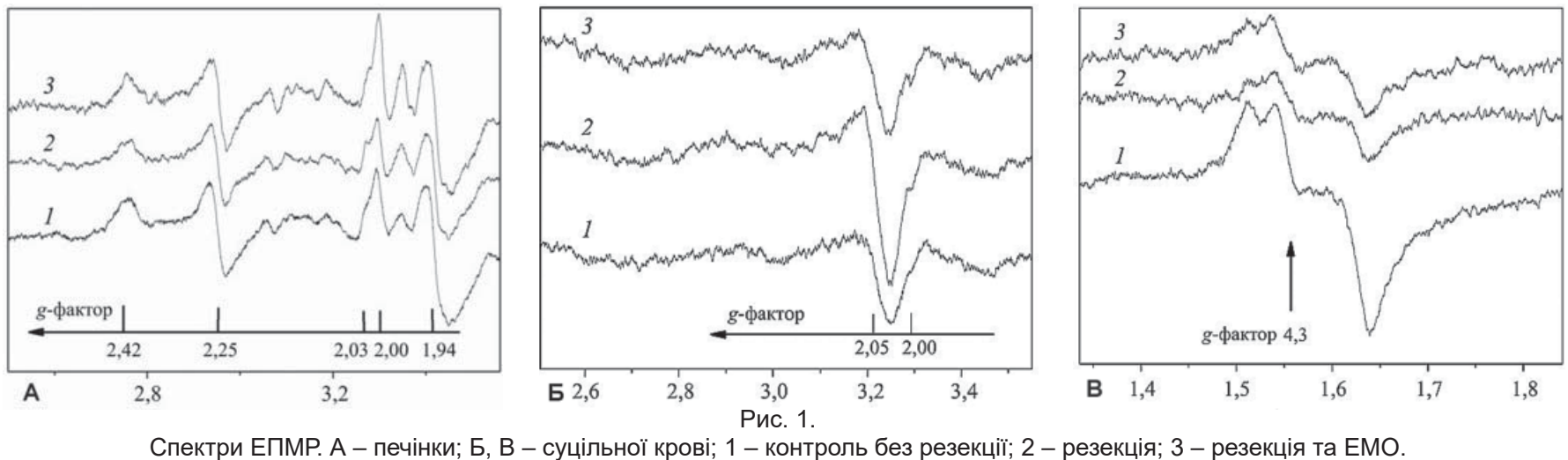

ко. Припускають, що при дії ЕМО в мембранах клітин коригується редокс-залежний стан внаслідок стимуляції електромагнітним полем перенесення електронів та протонів в цитохромній ділянці дихального ланцюга мітохондрій печінки за участю вільнорадикальних реакцій [6-8].

Аналіз цієї інформації свідчить, що для подальшої реалізації в медичних нанотехнологіях дистанційного контролю редокс-стану та ймовірності рекомбінації радикальних пар необхідне вирішення фундаментального питання, а саме, на які конкретні аспекти змін редокс-залежного стану після часткової резекції печінки впливає ЕМО при ііі регенерації $[9,10]$. Виходячи з цього, проведене дослідження змін окремих компонентів редокс-стану регенеруючої печінки під впливом ЕМО.

Робота виконана на нелінійних білих щурах-самках, маса тіла 230 - 250 г, розведення віварію Національного інституту раку. Тварин утримували в стандартних умовах віварію. Резекція печінки передбачала видалення медіальної та правої часток під комбінованим

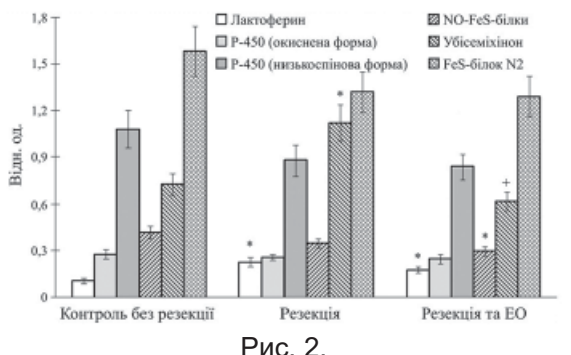

Зміни редокс-стану регенеруючої печінки під впливом ЕМO.

Статистично значущі відмінності порівняно з такими:

* у контрольній групі;

+ - у тварин 2-ї групи ( $<<0,05)$. наркозом (тіопентал-натрію 30 мг/ кг, каліпсол 100 мг/кг) [11].

Тварини розподілені на три групи: 1-ша група - контроль без впливу, 2-га група - часткова резекція печінки без ЕМО, 3-тя група - часткова резекція печінки та ЕМО протягом 1 год через день, 5 сеансів. Локальне неоднорідне ЕМО печінки здійснювали за допомогою експериментального прототипу апарата „Магнітерм” (Радмір, Україна), 3 частотою ЕМО 42 МГц, вихідною потужністю 75 Вт. ЕМО починали через 2 год після часткової резекції печінки. Температура всередині печінки не перевищувала $38^{\circ} \mathrm{C}$. Маса печінки у 1 -й групі тварин становила у середньому $(15,1 \pm 0,3) \Gamma$, на 7-му добу після резекції у 2-й і 3-й групах відповідно $(9,9 \pm 0,1)$ та $(11,3 \pm 0,2)$ г.

Для дослідження редокс-стану вивчали спектри ЕПМР після повної гепатектомії на 7-му добу після часткової резекції печінки на основі аналізу спектру ЕПМР за фіксованих значень g-фактору [12]. Спектри ЕПМР реєстрували на комп'ютеризованому спектрометрі марки РE1307 в циліндричному резонатоpi $з$ модою Н011 за частоти $(9,15 \pm$ 0,01) ГГц. Потужність надвисокочастотного випромінювання становила 40 мВт. Використовували модуляцію магнітного поля з амплітудою 10 Гс та частотою 100 кГц. Зразки печінки досліджували в парамагнітно чистому кварцовому Дьюарі при температурі $-196{ }^{\circ} \mathrm{C}$ (рідкого азоту). Об'єм проби 30 мкл [13].

Дослідження на тваринах здійснювали за нормами, встановленими законом України № 3447 - IV „Про захист тварин від жорстокого поводження" і вимог Європейської конвенції з захисту хребетних тварин, яких використовують для екс- периментальних і наукових цілей (20.09.1985).

Статистичний аналіз отриманих даних проводили з використанням t-критерію Ст'юдента, 3 попередньою перевіркою гіпотези про нормальний закон розподілу випадкової величини за критерієм Колмогорова-Смірнова. Для аналізу даних використовували пакет прикладних програм Statistic 6.0 та Prism 4.0.

На рис. 1 наведені спектри ЕПМР досліджених зразків печінки та крові тварин. Спочатку послідовно проаналізуємо обчислені при фіксованих значеннях g-фактору редоксформуючі компоненти печінки лактоферин, цитохром P-450, NOFes-білки, убісеміхінон і FeS-білок N2 (puc. 2).

Залізовмісний білок лактоферин, що належить до сімейства трансферинів, визначали на основі аналізу зареєстрованого сигналу ЕПМР $3 \mathrm{~g}$ $=4,25$. В тканині печінки після iii peзекції у тварин виявлене збільшення вмісту лактоферину до $(0,23 \pm 0,03)$ відн. од. порівняно з таким в печінці неоперованих тварин - $(0,11 \pm 0,02)$ відн. од. При ЕМО тварин після резекції печінки відзначали дещо менше збільшення цього показника лише до $(0,18 \pm 0,02)$ відн. од.

Цитохром Р-450 - група ферментів, що каталізують реакції окиснення органічних речовин, його вміст визначали для окисненої форми на основі інтенсивності сигналу ЕПМР при $\mathrm{g}=2,42$ та для низькоспінової форми при $g=2,25$. Часткова резекція печінки та подальше іiі ЕМО ініціювали лише тенденцію до зниження рівня низькоспінової форми цитохрому $\mathrm{P}-450$ відповідно до $(0,88$ $\pm 0,10)$ i $(0,84 \pm 0,08)$ відн. од. порівняно 3 таким у контрольній групі - 
$(1,08 \pm 0,12)$ відн. од. Сигнал ЕПМР окисненої форми цитохрому $\mathrm{P}-450$ взагалі не змінювався.

Функціональний стан ЕТЛ мітохондрій печінки визначали за зміною рівня комплексів NO-FeSбілків ( $\mathrm{g}=2,03)$, убісеміхінону ( $\mathrm{g}=$ 2,0023) та FeS-білків N2 ( $\mathrm{g}=1,94)$. Найбільш суттеві зміни спостерігали в спектрі ЕПМР при $\mathrm{g}=2,0023$, де визначали вміст убісеміхінону. Так, після резекції печінки та ЕМО рівень убісеміхінону становив $(0,62 \pm 0,06)$ відн. од., після резекції - $(1,12 \pm 0,12)$ відн. од. Рівень комплексів NO-Fesбілків після резекції печінки та у оперованих тварин після ЕМО зменшувався відповідно до $(1,32 \pm 0,13)$ та $(1,29 \pm 0,13)$ відн. од., у контрольній групі він становив $(1,58 \pm 0,16)$ відн. од. Після часткової резекції та ЕМО в усіх експериментах рівень $\mathrm{FeS}-б і л-$ ків N2 не змінювався.

Для більшого розуміння впливу змін редокс-стану регенеруючої печінки під впливом ЕMO на метаболічні процеси в усьому організмі проаналізовані сигнали ЕПМР у крові тварин щодо активності мідьвмісного білка церулоплазміну ( $\mathrm{g}=2,05)$ та залізовмісного білка трансферину $(\mathrm{g}=4,25)$ (див. таблицю). Після лише часткової резекції печінки активність церулоплазміну збільшувалась на 96\%, вміст трансферину - зменшувався на 60\%; після часткової резекції та ЕМО печінки порівняно 3 експериментом, де здійснювали лише резекцію печінки, активність церулоплазміну зменшувалась на 38\%, вміст трансферину - не змінювався.

Отримані дані підтверджують, що ЕМО сприяє інтенсифікації регенеративних процесів у печінці [6]. Про це безпосередньо свідчить і збільшення маси печінки в опромінених тварин після іiі резекції. Проте, ці емпіричні результати обмежені, вони не дають розуміння базових основ редокс-залежних ефектів регенераціiі. Тому, виходячи з впливу ЕМО на перенос електронів в клітині, проаналізуємо цей ефект з точки зору експериментальних результатів що-

\section{REFERENCES}

1. Nordlinger B, Guiguet M, Vaillant J-C, et al. Surgical resection of colorectal carcinoma metastases to the liver: a prognostic scoring system to improve case selection, based on 1568 patients. Cancer. 1996;77(7):1254-62.

2. Ellis LM, Curley SA, Grothey A. Surgical resection after downsizing of colorectal liver metastasis in the era of bevacizumab. J Clin Oncol. 2005;23(22):4853-5. мітохондрій [13].
Активність церулоплазміну та вміст трансферину у крові тварин

\begin{tabular}{|c|c|c|}
\hline \multirow{2}{*}{ Експеримент } & \multicolumn{2}{|c|}{ 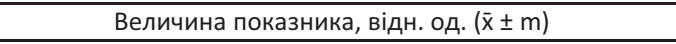 } \\
\hline & церулоплазміну & трансферину \\
\hline Контроль без резекції & $0,54 \pm 0,05$ & $1,21 \pm 0,13$ \\
\hline Резекція & $1,06 \pm 0,11^{*}$ & $0,49 \pm 0,05^{*}$ \\
\hline Резекція та ЕMO & $0,66 \pm 0,06 * *$ & $0,56 \pm 0,05^{*}$ \\
\hline
\end{tabular}

до змін редокс-стану регенеруючої печінки під впливом ЕМО. За нормальних умов гепатоцити не діляться і перебувають у фазі GO. Після резекції печінки вони входять у фазу G1. Індукція редокс-шляхів під час проліферації клітин після резекції потребує значних енергетичних витрат [14]. Це підтверджує збільшення на $109 \%$ ( $<<0,05)$ рівня металовмісного білка лактоферину після часткової резекції печінки порівняно 3 таким в неоперованій печінці. Сигнал ЕПМР окисненої та низькоспінової форм цитохрому Р-450 достовірно не змінився у тварин 2-ї та 3-ї груп порівняно з таким у контролі. Імовірно, ферменти цієї групи ініціювали порівняний ефект каталізу в проведених дослідженнях.

Зміни функціонального стану ЕТЛ мітохондрій печінки були такими. За часткової резекції печінки та ЕMO вміст FeS-білка N2 не змінився. За поєднаного впливу резекції печінки та ЕМО відзначене зменшення на 29\% (p < 0,05) вмісту комплексів NOFeS-білків порівняно з таким у контролі. Після часткової резекції печінки спостерігали збільшення рівня убісеміхінону на 53\%. Під впливом ЕМО після резекції виникли зміни ЕТЛ мітохондрій під час регенерації печінки. Так, порівняно з оперованою регенеруючою печінкою у тварин після ЕМО в ЕТЛ мітохондрій печінки виявляли зменшення рівня убісеміхінону на 45\% (p < 0,05). Це свідчило про вплив ЕMO на функціонування Q-циклу комплексу III (убіхінон-цитохром с-редуктаза) ЕТЛ

Це свідчило про можливість впливу ЕMO на дерегуляцію переносу електронів в ЕТЛ мітохондрій та модуляцію іх функцій у клітинах регенеруючої печінки після іiі резекціi. При переносі вільних електронів в ЕТЛ мітохондрій у фізіологічно низькій кількості ( 1 - $2 \%$ загальної кількості споживання кисню) змінюються редокс-стан клітини та швидкість генерування супероксидних радикалів $[15,16]$. Гіпотетичне узагальнення полягає в тому, що виток електронів 3 мітохондрій істотно впливав на генерацію активних форм кисню як регуляторних підсилюючих сигналів в клітинних процесах при регенерації печінки за участю фактору транскрипції Nrf2.

Підтвердженням змін редокс-стану регенеруючої печінки було зменшення рівня мідьвмісного білка церулоплазміну у 2,2 разу у крові тварин після резекції печінки та ЕМО порівняно з таким лише в оперованих тварин. Це свідчить про взаємоючої печінки під впливом ЕМО з метаболічними процесами в усьому організмі.

Таким чином, вплив ЕMO, підсилюючи процеси регенераціі печінки після іï резекції, змінює іiі редокс-стан, при цьому вираженість змін редокс-формуючих компонентів має кількісні особливості порівняно $з$ процесами регенерації лише в оперованих тварин. В перспективі це відкриває можливості використання синергетичного впливу ЕМО та наномагнітних структур для дистанційного керування процесами редокс-стану і кінетикою проліферації клітин при регенерації печінки після ії резекції у пацієнтів при онкологічних захворюваннях [17]. зв'язок змін редокс-стану регенеру-

3. Diesen DL, Kuo PC. Nitric oxide and redox regulation in the liver: Part I. General considerations and redox biology in hepatitis. J Surg Res. 2010;162(1):95-109.

4. Caraceni P, Domenicali M, Vendemiale G, et al. The reduced tolerance of rat fatty liver to ischemia reperfusion is associated with mitochondrial oxidative injury. J Surg Res. 2005;124:160-8.

5. Hu M, Zou Y, Nambiar SM, et al. Keap1 modulates the redox cy- 
cle and hepatocyte cell cycle in regenerating liver. Cell Cycle. 2014;13(15):2349-58.

6. Ottani V, Monti MG, Morocutti M, et al. Influence of pulsed electromagnetic fields on regenerating rat liver after partial hepatectomy. $J$ Anat. 1984;139(2):253-63.

7. Sadovnikova VV, Lobko ZG, Sadovnikova IV. Stimulation of hepatocyte proliferation in normal and pathologically altered liver exposed to a pulsed magnetic field. Biull Eksp Biol Med. 1993;115(3):295-7.

8. Barnes FS, Greenebaum B. The effects of weak magnetic fields on radical pairs. Bioelectromagnetics. 2015;36(1):45-54.

9. Banci L, Bertini I, Cefaro C, et al. An intrinsically disordered domain has a dual function coupled to compartment-dependent redox control. J Mol Biol. 2013;425(3):594-608.

10. Cohen AE. Nanomagnetic control of intersystem crossing. J Phys Chem A. 2009;113(41):11084-92.

11. Madrahimov N, Dirsch O, Broelsch C, et al. Marginal hepatectomy in the rat: from anatomy to surgery. Ann Surg. 2006;244(1):89-8.
12. Blumenfeld L. Problems of biological physics. Berlin: Springer-Verlag; $1981.233 \mathrm{p}$.

13. Burlaka AP, Sidorik EP. Redokszavisimye signalnye molekuly v mekhanizmakh opukholevogo protsessa. Kyiv: Naukova dumka; 2014. 255 c. [In Ukrainian].

14. Mohammed FF, Khokha R. Thinking outside the cell: proteases regulate hepatocyte division. Trends Cell Biol. 2005;15:555-63.

15. Stowe DF, Camara AKS. Mitochondrial reactive oxygen species production in excitable cells: modulators of mitochondrial and cell function. Antioxidants \& Redox Signaling. 2009;11(6):1374-414.

16. Jastroch M, Divakaruni AS, Mookerjee S, et al. Mitochondrial proton and electron leaks. Essays Biochem. 2010;47:53-67.

17. Orel V, Shevchenko A, Romanov A, et al. Magnetic properties and antitumor effect of nanocomplexes of iron oxide and doxorubicin Nanomed Nanotech Biol Med. 2015;11:47-55. 